International Review of Research in Open and Distributed Learning Volume 18, Number 4

June - 2017

\title{
Tracking the Money for Open Educational Resources in South African basic Education: What We Don't Know
}

\author{
Sarah Goodier \\ Centre for Innovation in Learning and Teaching, University of Cape Town
}

\begin{abstract}
Limited research has been done to date on the extent of public funding of Open Educational Resources (OER) within basic education (K-12 equivalent) in South Africa. As claims have been made about the potential cost reductions that come with using OER, this study aimed to establish a benchmark of public spending on educational resources, uncover how much is being spent on OER and assess cost-savings of OER adoption.

A desk review and document analysis of official information sources on South African basic education was conducted to develop a conceptual understanding of funding allocations the South African government uses for educational resources. A review of publicly available government reports and budgets showed that there is insufficient information at this time to determine how much is being spent on OER specifically or to act as a benchmark for potential cost savings of OER. This study highlights the information gaps which would need to be filled in order to make claims about OER and their potential as cost savers.
\end{abstract}

Keywords: basic education, expenditure, allocation of funds, learning and teaching support material, OER, South Africa

\section{Introduction}

In terms of potential cost-saving mechanisms, Open Educational Resources (OER) have been claimed as well as found in some cases to be a cost-effective mechanism for providing educational materials to students and educators in the USA (e.g. Allen \& Student PIRGs, 2010; Hilton III, Robinson, Wiley, \& Ackerman, 2014; Wiley, Hilton III, Ellington, \& Hall, 2012). However, OER cost-saving has not been investigated with regard to public funding of OER in South African basic education (K-12 equivalent) to date.

This study utilises the definition of OER laid out in the 2012 Paris OER Declaration; namely, that OER are 
teaching, learning and research materials in any medium, digital or otherwise, that reside in the public domain or have been released under an open licence that permits no-cost access, use, adaptation and redistribution by others with no or limited restrictions. (United Nations Educational, Scientific and Cultural Organisation [UNESCO], 2012, p. 1)

This study focuses on the use of public funding, defined here as money allocated by the South African National Treasury through the annual budget and appropriation process.

The aims of this study are to investigate whether any public funding is being channelled specifically into OER; and, if so, whether it is possible to calculate any potential cost savings that have been realised thus far. The backdrop of the study, including the high costs of education in the region, the importance of access to learning materials, and the potential for OER to reduce costs, is described below.

\section{Background}

The key role of education in societal and economic development is recognised in the right to primary education forming part of many international statements on human rights. This important right is also enshrined in the Constitution of the Republic of South Africa (Republic of South Africa, 1996), which makes provision for receiving education in any one of the country's 11 official languages. South Africa achieved the Millennium Development Goal (MDG) of universal primary education ahead of the 2015 target year (United Nations Development Programme [UNDP], 2012; United Nations Economic Commission for Africa [UNECA], 2015), demonstrating that access to primary education has increased. This broad-based access is, however, not cheap.

Currently, substantial amounts of money are spent on education by governments across the African continent, with average public expenditure on education in the region as a percentage of GDP increasing from $4.2 \%$ to $4.9 \%$ between 2000 and 2012 (UNECA, 2015). In South Africa, education expenditure has been on the increase for decades, from ZAR 31.1 billion in 1995, to ZAR 59.6 billion in 2002, and to ZAR 105.5 billion in 2007 (Organisation for Economic Co-operation and Development [OECD], 2008). In the current global climate of austerity there is a pressing need to maximise outcomes from increasingly limited resources.

Despite financial pressures within the education system, teaching and learning materials are recognised as foundational to learning. A Development Bank of Southern Africa (DBSA, 2012) review highlights adequate resources and 'instructional materials, such as textbooks, supplementary teachers' guides and materials, library books, and the like" (p. 196) as the basic inputs necessary in education, and among those that improve student achievement. In the South African context, such materials are referred to as Learning and Teaching Support Materials (LTSM) and this term will be used in this paper. LTSM, formerly called Learning Support Materials (LSM), refers to "a variety of learning and teaching materials used in classroom. These range from teacher and learner created resources to commercially produced classroom resources such as wall charts, workbooks, textbooks, e-books, readers, stationery, science kits, dictionaries, encyclopaedias, etc." (Department of Basic Education [DBE], 2014, p. 3). 
Textbooks have increasingly been seen as an important part of South African basic education following the 2009 Review of the Implementation of the National Curriculum Statement (Department of Basic Education [DBE], 2009; 2011). The Minister, in her 2009 Curriculum Review speech indicated that "the textbook is the most effective tool to ensure consistency, coverage, appropriate pacing and better quality instruction" (DBE, 2009, p. 1). This was because it was considered to be the primary delivery mechanism in providing both teachers and learners with the curriculum requirements (OECD, 2008); and served as a key tool in helping students to understand relationships between topics and concepts within topics, as well as being critical in enabling students to do homework (DBE, 2011). In developing countries, it has been found that children who have access to LTSM, such as textbooks, learn more relative to those without (Development Bank of Southern Africa [DBSA], 2012). Therefore, increasing expenditure on LTSM, despite the climate of austerity, to enable access to learning materials has been seen as valid (OECD, 2008).

In their Action Plan 2014, the Department of Basic Education (DBE) recognises the need for improved access to learning materials in South Africa. Two of the 27 goals listed in the Action Plan 2014 relate directly to learning materials:

Goal 19: Ensure that every learner has access to the minimum set of textbooks and workbooks required according to national policy.

Goal 20: Increase access amongst learners to a wide range of media, including computers, which enrich their education. (DBE, 2011, p. 6)

These goals originate from a historical legacy of a lack of access to required LTSM such as textbooks and other materials in South African schools (OECD, 2008). The Southern and Eastern African Consortium for Monitoring Educational Quality (SACMEQ) II and III results show no substantial change in South Africa for the percentage of sole-use access to Grade 6 reading textbooks (46\% and 45.0\%, respectively) (Spaull, 2012). This level of access is only approximately 3\% above the SACMEQ average (United Nations Educational, Scientific and Cultural Organisation International Institute for Educational Planning [UNESCO IIEP], 2010), and varies widely among provinces. A 2005 survey of 20 schools in three South African provinces found that in allocating the required learner support material, schools gave preference to Grade 12 as well as other secondary-school grades (Financial and Fiscal Commission, 2005). Despite this, the survey also found that delivery of the minimum number of textbooks required for Grades 8 to 11 was often not met (Financial and Fiscal Commission, 2005). In 2008, only 64\% of Grade 4 to 7 learners were in classes where every student had a mathematics textbook (DBE, 2011). These textbook access problems, especially in poorer schools, are a recognised obstacle to learning (DBE, 2011). Goal 19 stated above was therefore listed as a priority goal to be reached in 2014 (DBE, 2011).

Performance indicators in the 2015 Budget (National Treasury, 2015) indicate a high level of coverage in terms of learners' access to the required workbooks and textbooks. For example, the percentage of learners with access to the required textbooks in all school grades and in all subjects per year was $97 \%$ in 2011/12, $98 \%$ in 2012/13, and $91.8 \%$ in $2013 / 14$. It is, however, not stated whether this is individual access to the books or whether they are shared among learners. Therefore, while access has improved, Goal 19 was not reached. There have been reported instances of non-delivery and late delivery of 
textbooks to schools indicated by educators (Department of Basic Education [DBE], 2013b), as well as serious under-allocation of budget to provide the required textbooks (Nkosi, 2013). In December 2015, the Supreme Court of Appeal ruled that every child has a right to start off the school year with their textbooks, increasing the pressure on the DBE to deliver on providing timely access across the country (Supreme Court of Appeal of South Africa, 2015).

\section{Schools and OER: Evidence for Reduced Cost}

OER has been suggested by several stakeholders as a possible solution to both cost and access issues in education. Studies conducted in the United States, with a particular focus on tertiary education, have examined the cost of OER and the savings they can potentially facilitate. Allen \& Student PIRGs (2010) calculated potential savings for students by analysing the cost of textbooks from ten US college-level courses which had an open textbook available for that subject. An average annual saving of $80 \%$ was found (Allen \& Student PIRGs, 2010). Hilton III et al. (2014) found that the average cost of the standard textbook used for these same classes was USD \$90.61. Using a cost of zero for the OER, a potential saving of over USD 200 ooo dollars was found for all students $(n=2,642)$ enrolled in classes that used OER as textbooks in the Kaleidoscope Open Course Initiative (Hilton III et al., 2014).

What has been proposed is that using OER could potentially help to decrease the cost of educational resource acquisition in the long term, allowing countries to better meet the growing demand for education, while also potentially improving outcomes. Jimes, Weiss, and Keep, (2013) draw attention to the potential of OER to contribute "high-quality teaching and learning resources that can be freely used, shared, and modified by educators to suit local instructional needs" (p. 74). Governments that recognise this potential and its asserted link to reducing their costs have been shown to favour open textbooks (Frydenberg \& Matki, 2007). The DBE has printed and issued several OER textbooks to high school science and maths students since 2012 in partnership with OER publisher Siyavula (Attwell, 2012; Department of Basic Education [DBE], 2012; 2013a; Frydenberg \& Matki, 2007; Jimes, Weiss, \& Keep, 2013; Shillington, 2012). This presents an opportunity to potentially investigate whether OER has reduced costs. Comparing open textbook costs those associated with traditional textbooks is an important step in producing evidence for or against cost reduction. For example, if an open and traditional textbook cost the same to produce, the open textbook could still represent a longer-term cost advantage as it could be revised and the relevant sections printed and combined with the original instead of an entirely new book being produced and printed. Establishing whether these textbooks can or already do result in reduced costs would provide vital information to government and other stakeholders in guiding the way forward.

\section{Context of the Present Study}

This study is aimed at understanding whether the utilisation of OER would result in cost savings in the South African basic education context. As such, the specific objectives of this study have been to:

- Review information sources on basic education provision and policy in South Africa in order to understand and establish a baseline for the allocation of funds used by government to develop and/or buy educational resources for basic education.

- Ascertain whether any public funding has been channelled specifically into OER production and/or acquisition in South Africa. 
- Determine whether and to what extent, from the established baseline, OER represent a cost reduction with regards to educational resource acquisition in basic education in South Africa.

These ambitions are embodied in the following research questions:

1. How much public money is currently spent on the production and acquisition of educational materials in basic education in South Africa?

2. How much public money is currently being spent on OER production and acquisition in basic education in South Africa?

3. To what extent do OER represent a cost reduction with regards to educational resource acquisition in basic education in South Africa?

\section{Method}

Data on expenditure regarding education "are essential for effectively addressing critical education policy questions" (United Nations Educational, Scientific and Cultural Organisation Institute for Statistics [UNESCO IS], 2011, p. 11). These kinds of data can provide insight into where it may be possible to lower costs. However, information on the allocation of funds from public sources specifically around educational resource acquisition and development (including digital objects, textbooks, learning platforms, scientific books, and publications) is not necessarily readily available beyond publicly available government budgets and expenditure reports. To track the allocation of funds it was necessary to develop an understanding of the structure of education departments and how they acquired and distributed their funding.

An extensive desktop review surveying studies, reports, and other literature on cost in education was undertaken in order to identify, access and review official information sources on South African education in order to understand the government allocation of funds into the production and acquisition of LTSM. Information on any funding contributing to the production and acquisition of OER was also reviewed. The sources of information used are summarised in Table 1.

Table 1

Primary Document Analysis Sources by Research Question

\begin{tabular}{|l|l|l|}
\hline Research question & $\begin{array}{l}\text { Information source } \\
\text { (organisation type) }\end{array}$ & Document/data type \\
\hline $\begin{array}{l}\text { 1: How much public money is } \\
\text { currently being spent on the } \\
\text { production and acquisition of } \\
\text { educational materials in basic } \\
\text { education in South Africa? }\end{array}$ & $\begin{array}{l}\text { Government information sources } \\
\text { International and regional } \\
\text { systems and expenditure } \\
\text { Media }\end{array}$ & $\begin{array}{l}\text { National budgets } \\
\text { Provincial budgets } \\
\text { Government policy documents } \\
\text { Government reports } \\
\text { Government websites }\end{array}$ \\
\hline
\end{tabular}




\begin{tabular}{|l|l|l|}
\hline & & $\begin{array}{l}\text { Organisation reports } \\
\text { Organisation data } \\
\text { News reports }\end{array}$ \\
\hline $\begin{array}{l}\text { 2: How much public money is } \\
\text { currently being spent on OER } \\
\text { production and acquisition in } \\
\text { basic education in South } \\
\text { Africa? }\end{array}$ & $\begin{array}{l}\text { Government information sources } \\
\text { International and regional } \\
\text { systems and expenditures } \\
\text { Media }\end{array}$ & $\begin{array}{l}\text { National budgets } \\
\text { Provincial budgets } \\
\text { Government policy documents } \\
\text { Government reports } \\
\text { Government websites } \\
\text { Organisation reports } \\
\text { Organisation data: } \\
\text { News reports }\end{array}$ \\
\hline $\begin{array}{l}\text { 3: To what extent do OER } \\
\text { represent a cost reduction } \\
\text { with regard to educational } \\
\text { resource acquisition in basic } \\
\text { education in South Africa? }\end{array}$ & $\begin{array}{l}\text { Government information sources } \\
\text { International and regional } \\
\text { organisations that track educational }\end{array}$ & $\begin{array}{l}\text { National budgets } \\
\text { Provincial budgets } \\
\text { Government policy documents } \\
\text { Government reports } \\
\text { Government websites }\end{array}$ \\
& $\begin{array}{l}\text { Organisation reports } \\
\text { Organisation data: } \\
\text { Documentation from Siyavula }\end{array}$ \\
\hline
\end{tabular}

As this is an exploratory review of a topic that is documented in both academic as well as public and government literature, online searches were conducted in both general search engines (Google and Yahoo) as well as in academic databases (Google Scholar, EBSCOHost) and a repository (CSIR ResearchSpace). The search terms used, in various combinations, were "educational expenditure," "South Africa," "textbook," "DBE," "procurement process," "public funding," "National Norms and Standards for School Funding," "quintile system," "government budgeting," "department of basic education," "provincial departments of education," "OER," "open educational resources," "primary education," "OER cost," "cost," "Africa," "basic education," "secondary education," and "Siyavula open textbook." Specific websites, such as the DBE's website (http://www.education.gov.za/), the National Treasury site (http://www.treasury.gov.za/), and newspaper websites were also searched. Sources of information were included if they carried information relevant to educational expenditure funding allocation in South African basic education, or had any particular reference to OER.

\section{Findings}

The key findings from the desk review and document analysis of official information sources on South African basic education are presented in a narrative below.

\section{Provincial versus National Budget Allocation in the South African Basic Education System}

Since the bifurcation of the South African National DOE in 2009, the responsibility for education has been shared by the DBE and DHET (Department of Basic Education [DBE], n.d.). DHET is responsible for universities as well as other post-school education and training; while schools, from Grade $\mathrm{R}$ (the 
Reception year in the South African school system; similar to kindergarten) to Grade 12, and adult basic education are the responsibility of the DBE (Government Communications and Information Systems Department, 2014). Schooling is compulsory from age 7 to 15 or up to the end of Grade 9, whichever occurs first, and the majority of students do in fact complete Grade 9 (OECD, 2008; van Wyk, 2015). One of the drivers for compulsory education is the historical context of restricted access to education in South Africa under the Apartheid system. It is, as such, designed to address the need to "make education structurally accessible to all who were previously denied, or had limited access to it" (OECD, 2008).

Under the National Education Policy Act No. 27, the DBE (1996a) is responsible for determining national education policy and monitoring its implementation by the Provincial Departments of Education (PDEs). It is, however, the PDEs that are responsible for implementing policies aligned with national government goals and allocating their own budgets (determined by provincial allocations) based on the number of schools and students in their areas. As with all government departments, the DBE and DHET are funded through the annual national budget allocation and appropriation process. The same process also applies to the provinces, which in turn provide the funds for their provincial departments of education. These processes are described below.

The Public Finance Management Act No. 1 of 1999 regulates national and provincial government financial management and outlines the responsibilities of those in charge; while the National Treasury manages the country's budget preparation process and its implementation. All money received by the national government, for example taxes collected by the South African Revenue Service (SARS), is deposited into the National Revenue Fund, and there are provincial treasuries which prepare and implement the budget for each province. Parliament and the provincial legislatures must devote money for specific purposes for each financial year that fulfil the requirements of the state and the provinces, respectively. The annual budget is tabled in February in the National Assembly by the Minister of Finance preceding the start of the financial year, following which the Member of the Executive Council (MEC) for Finance in each province tables the annual provincial budget. The budget allocates money to the national, provincial, and local spheres of government. Money from the national budget allocation funds government departments such as the DBE and DHET, while money from the provincial allocation funds the PDEs. Each province receives an equitable provincial share, which is the overall amount determined by the Parliament of South Africa to fund the provision of provincial services. This equitable share is calculated by a formula taking into account various factors, such as the provincial population. The percentage allocation that goes to various provincial sectors (such as education) is determined by the Provincial Legislature - not national government or the DBE (DBE, 2011). This funding process is outlined in Figure 1. 


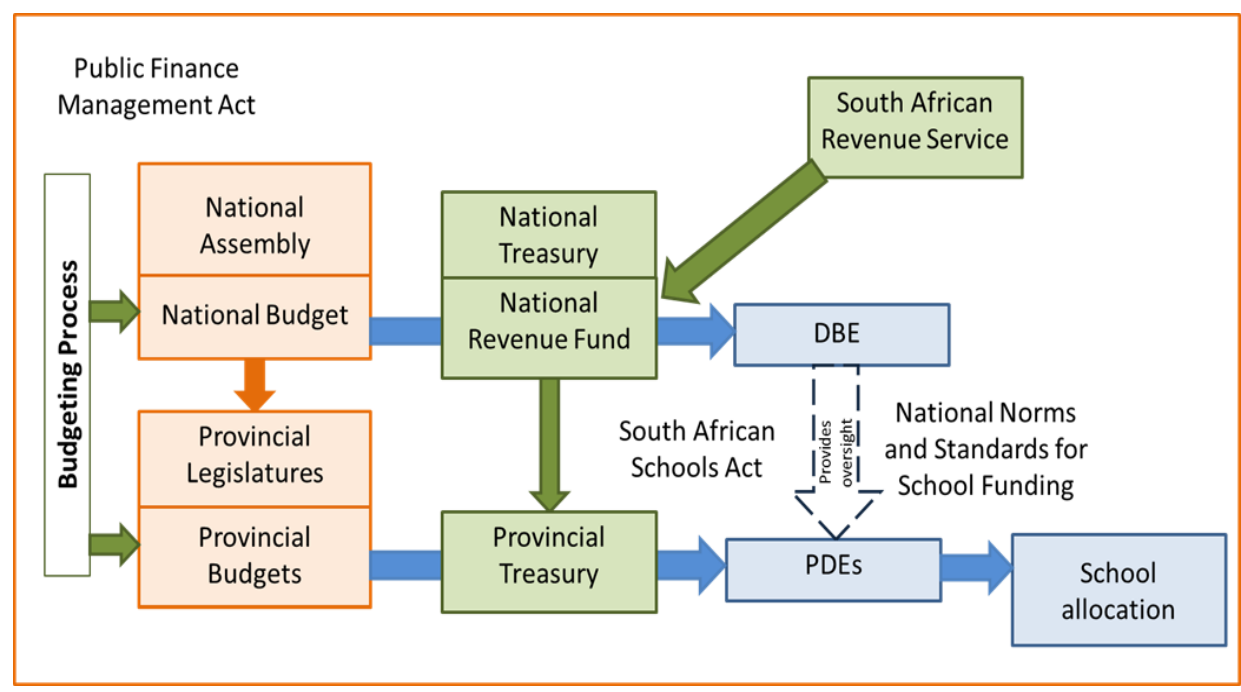

Figure 1. Simplified schematic of the national budgeting and allocation process for basic education. Orange boxes indicate national and provincial government budgeting, green boxes indicate Treasury allocation, while blue boxes indicate DBE, PDE, and schools.

The South African Schools Act No. 84 of 1996 provides for the establishment and administration of public schools from provincial legislature funds in the Provincial Treasury (Department of Education [DOE], 1996b). The responsibility for this provision rests with the MEC for Education. The PDEs receive the funds and distribute them in line with their budgeting process (DBE, 2011; DOE, 2006). Every PDE budget will contain a line item for teaching and learning materials, including textbooks that are prescribed for each grade. This makes tracking expenditure on a specific category of items possible, at least at PDE level.

The National Norms and Standards for School Funding established public school allocations (DOE, 2006). As each province takes responsibility for its schools, and the school allocation budgets and expenditure priorities can be different, what is considered appropriate in terms of norms and standards can vary widely between the provinces (Pitt \& Beckett, 2014b, para. 3). School allocations are defined as "an amount allocated by the state to each public ordinary school in the country on an annual basis in order to finance non-personnel non-capital expenditure items" (DOE, 2006, p. 24). The annual school allocations made include provision for expenditure on LTSM (DOE, 2006). The LTSM procurement and delivery process is described below.

\section{Procurement and Delivery of LTSM}

The Executive Director of Publishers' Association of South Africa (PASA), in his supporting affidavit to Section 27's legal action against the DBE regarding the 2012 textbook crisis in the South African province of Limpopo, described the textbook procurement and delivery process presented in Figure 2 below (Wafawarowa, 2012). Once the National Catalogue is produced by the DBE, PDEs liaise with schools around their requisition forms for these books and usually place consolidated orders in August/September of the year preceding the academic year the books are required for. When orders are received, PASA members move to supply the books, and orders placed by September are filled prior to the December school holidays. Later ordering results in later delivery, but even when orders are placed in 
December/January, books are usually still received early in the year. However, if books are not in stock and need to be printed, a time lag of eight weeks can pass before delivery. Books are usually delivered to the PDE's central warehouse rather than directly to the schools; the PDE then delivers the textbooks to the schools.

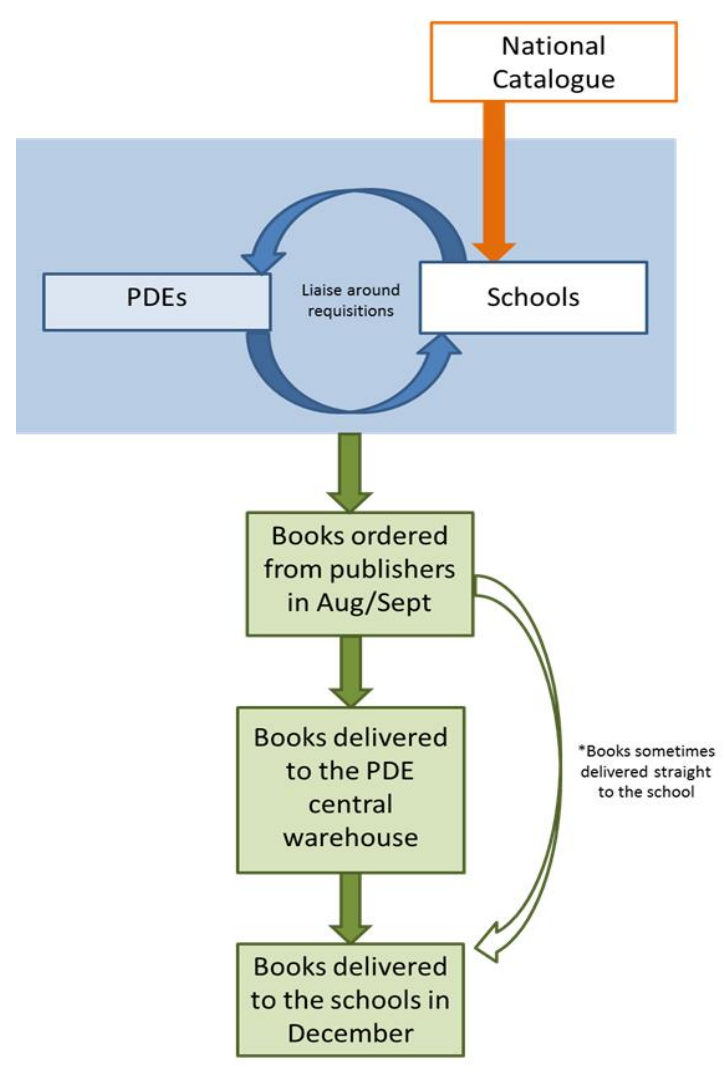

Figure 2. Simplified schematic of the South African basic education textbook procurement process.

LTSM (including textbooks) form a large part of the South African publishing industry's print output, with the government as one of its largest consumers (Publishers' Association of South Africa [PASA], 2004). The cost to government is substantial, as approximately ZAR 1.5 billion is paid to the publishing industry annually for orders of textbooks by the DBE (Butcher \& Hoosen, 2012). In terms of LTSM, the National Catalogue of Textbooks (established in 2011) reflects the catalogue of textbooks reviewed and recommended by the DBE, enabling choice and, potentially, better value through negotiations and economy of scale (Department of Basic Education [DBE], 2013a). The timing of the release of this list has implications for ordering and the DBE noted that releasing the list early in 2012 allowed the PDEs to order with sufficient time to ensure that delivery of the curriculum-aligned books could take place in time for the 2013 school year (DBE, 2013a).

While Figure 2 shows the process for book ordering from traditional publishers, there has been one case where OER textbooks have been supplied to schools through a partnership between an OER publisher and the DBE. 


\section{A South African OER Initiative}

Founded in South Africa in 2007, Siyavula is an education technology company and OER publisher that aims to make open textbooks and other content "available for all grades and subjects within South Africa" (Siyavula, 2015a, para. 2). Released under Creative Commons licenses (Creative Commons, n.d.), these resources are free for users to print and adapt as needed, depending on the licence chosen.

Siyavula has successfully partnered with the DBE (Siyavula, 2015b, para. 6) to review and endorse the open textbooks Siyavula produces, and enable the printing and distribution of free-to-the-user copies of their textbooks, Everything Maths and Everything Science, and their Thunderbolt Kids workbooks for Grades 4-6 in natural science and technology to all government schools across the country (Attwell, 2012; DBE, 2012; 2013a; Jimes et al., 2013; Shillington, 2012). In 2012, government printers printed both the Siyavula Everything Maths and Everything Science textbooks, teacher guides for Grades 10, 11, and 12, and the Grade 4-6 workbooks (DBE, 2013a; Shillington, 2012). It is, however, unclear exactly how many books were actually printed or which budget(s) the costs were recovered from. Shillington (2012) cites approximately 2.5 million books being printed at a cost of ZAR 35 a copy, while the DBE (2013a) indicate that four million were printed. In January 2013, Grade 11 books were distributed again and there was a plan to distribute the books to Grade 12 learners in 2014 (DBE, 2013a). From 2012 to date, it is estimated that approximately 10 million Siyavula textbooks have been printed and distributed to schools all over the country by government (Pitt \& Beckett, 2014a). As the total print numbers and costs, as well as distribution costs are not available, actual unit costs cannot be accurately calculated.

In terms of internal content development costs, Siyavula produces textbooks as OER through a sponsorship model where a sponsor signs on to fund production costs in exchange for advertising in the books, which I one of the factors that makes the books cheaper for the government. A comparison between Siyavula's model and traditional textbook publishing, in terms of cost recovery, is shown in Figure 3 .

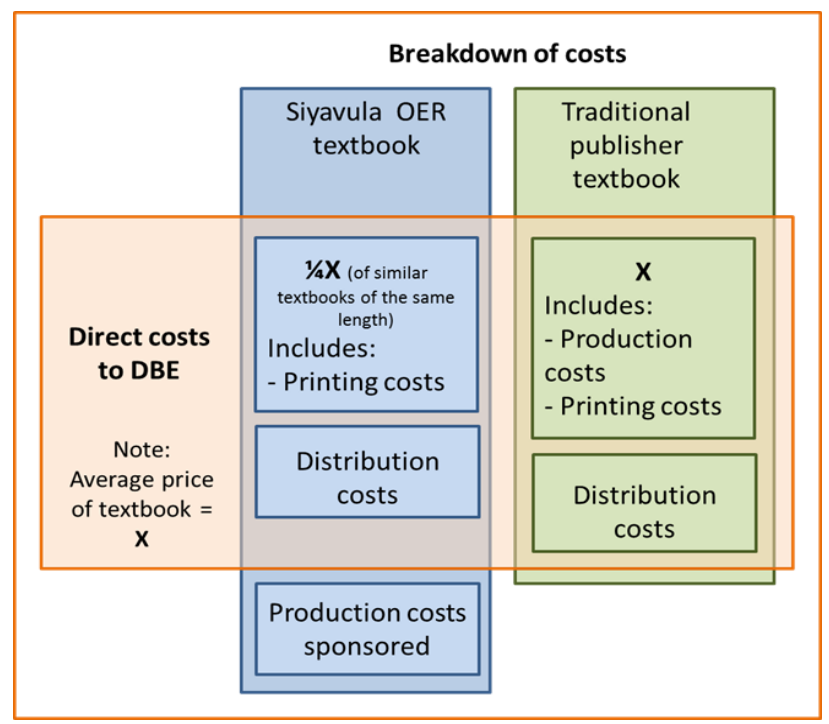


Figure 3. Siyavula textbook costing model versus traditional textbook publishing model highlighting basic cost information needed to calculate any savings from using OER: production, printing and distribution costs. This does not include additional factors such as profit margin or royalties.

As a cost-saving option to government, the Siyavula textbooks have been noted to be attractive as these books cost "a quarter of the unit price of similar textbooks of the same length" (DBE, 2013a, p. 14). However, the data to substantiate this claim are not provided and no analysis of cost difference or the figure to conduct one were found during this study. Therefore, although the Siyavula case provides some evidence for the availability of mathematics and science OER in the form of textbooks in South African basic education, there is little and conflicting available information on their distribution and printing and the costs associated with these. This makes it difficult to even estimate cost to public sources or determine which budgets covered these costs.

\section{Challenges in Tracking LTSM-Related Expenditure}

As illustrated above, tracking allocation of funds and expenditure on specific categories of items is difficult due to the complex nature of the funding structures, with expenditure spread across various budgets and levels of government. In terms of the National Norms and Standards for School Funding, funds for LTSM are allocated by provinces (DOE, 2006).

The actual and projected expenditure amounts on LTSM by PDE, as reported in the 2014 National Treasury provincial budget documentation (National Treasury, 2014a-i), are presented in Figure 4. Figure 4 shows the LTSM allocations from the annual 2010/11, 2011/12, and 2012/13 budgets, the adjusted appropriation from the 2013/14 budget, and the medium-term estimates for the 2014/15, 2015/16 and 2016/17 financial years for each province In 2013/14, just over 3.8 billion ZAR was the total appropriation for all provinces, with an average of 0.424 billion ZAR per province. Most provinces, except for the Free State and Northern Cape, show a general upward trend in LTSM expenditure since 2010/11. The large differences in education expenditure and budget between provinces as well as between years reflects the different priorities from year to year in terms of educational budget expenditure and the relative need for LTSM acquisition, which can be affected by number of learners and which books they require. Therefore, while the overall baseline of LTSM spend per year can be obtained, there is no detail available in these PDE budgets to separate out any OER spend from the overall LTSM spend. 


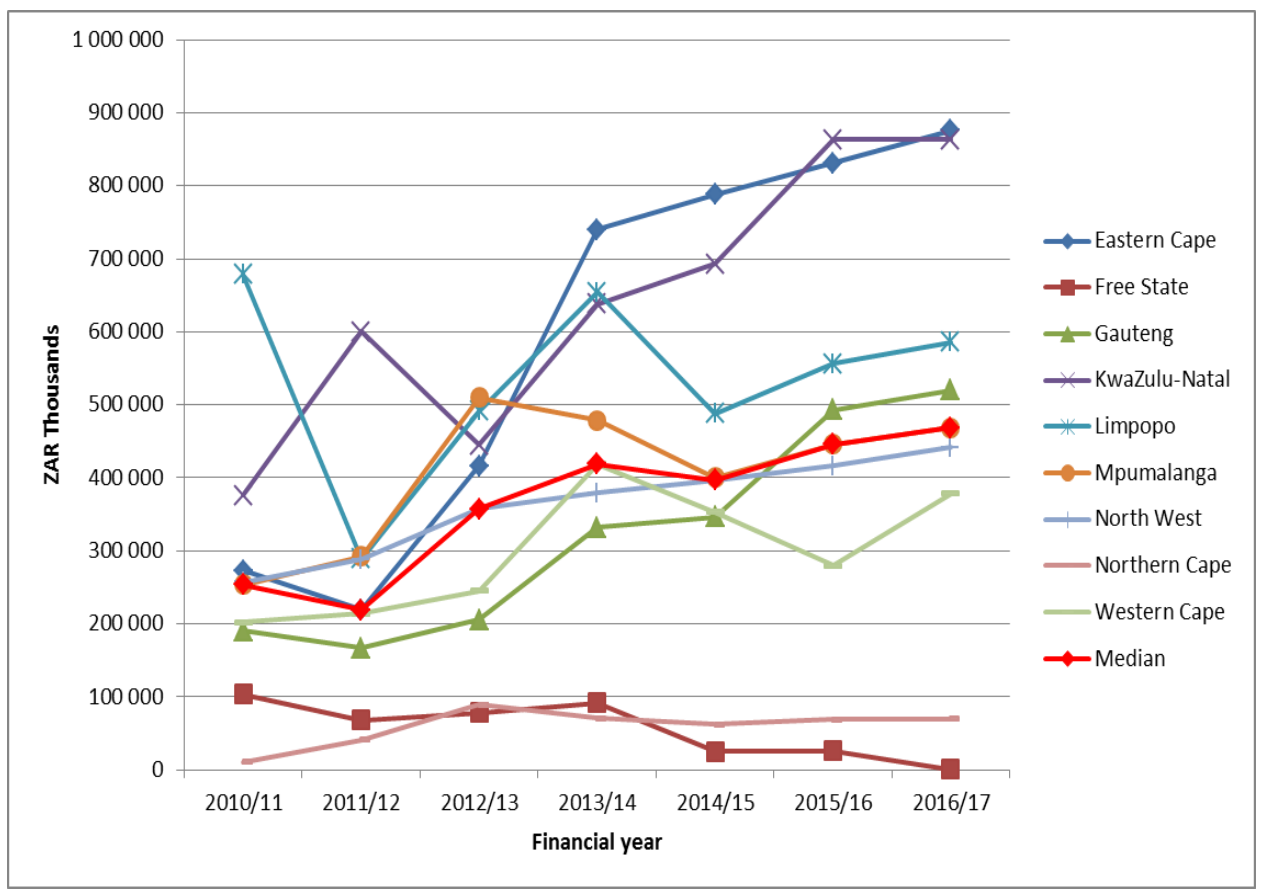

Figure 4. Budget allocations for LTSM by PDE (2010-2017). As these are from 2014 budget figures, 2014/15, 2015/16, and 2016/17 are projected figures (source National Treasury, 2014a-i).

In terms of the DBE's budget and expenditure on LTSM, it is not clear how much money was spent on LTSM-related purchases and, by extension, OER. There is no line item for LTSM in the programme budget breakdowns in the national budgets and it is unclear where printing or distribution of these resources, for example in the Siyavula case, might fit into the budget categories.

\section{Discussion and Conclusion}

In aiming to meet the Constitutional obligation to be able to make provision for primary education to be received in any one of the country's 11 official languages (Republic of South Africa, 1996), as well as the DBE's Action Plan goals related to providing access to the minimum prescribed resources (DBE, 2011), OER has the potential to enable (legally translatable) resources that could potentially be cheaper than traditional textbooks in the longer term. These books could be printed and distributed as well as shared electronically. There has also been a growing focus on digital resources and access platforms, with both the Gauteng and Western Cape Education Departments recently launching digital education initiatives (Louw, 2015; Western Cape Government, 2015). This is in line with trends elsewhere around the globe where basic education continues to incorporate digital components (Brown \& Green, 2015) as a strategy to maximise public spending and improve quality (Toledo, Botero, \& Guzmán, 2014). Having resources available on these platforms explicitly under an open license would help to facilitate adoption and use as well as potentially reduce costs over time. In order to calculate any cost savings, however, cost benchmarks as well as OER spend data would need to be available. 
While broad figures on LTSM expenditure by PDEs were available in government budgets, insufficient information is currently available to track any OER spend, or to ascertain any possible cost-savings that the adoption of OER might bring. The level of detail in the available government information does not provide a usable benchmark for a cost-saving analysis. The lack of this information has been found elsewhere in the global south. Toledo et al. (2014) were similarly not able to gather such information in their Latin American study examining expenditure in Argentina, Chile, Paraguay, Uruguay, and Colombia, as it was either not available from the government departments or not compiled in a useable state.

Further research into LTSM expenditure and allocation of funds for OER could inform better decisionmaking on where resources should be directed. Information on the allocation of funds from public sources into educational resource acquisition and development is, however, not necessarily readily available beyond government budgets and expenditure reports, and those reviewed do not provide the level of detail required to attempt a cost-benefit analysis regarding the introduction of OER. Filling these important information gaps highlighted above would provide the data to begin to calculate how much public money is currently being spent on OER in basic education in South Africa and whether this has resulted in any savings. Examples of the information needed to establish a baseline and measure any potential cost savings are included in Figure 5 below.

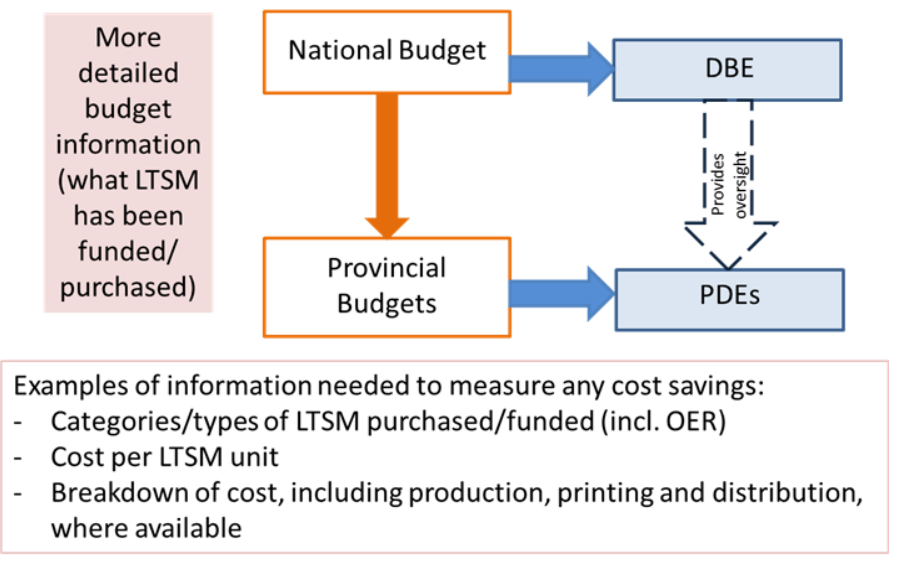

Figure 5. Information gaps identified in the national budgeting and allocation process for basic education. Orange boxes indicate national and provincial government budgeting, while blue boxes indicate education departments.

While the Siyavula OER initiative example provides some indication of the categories of costs involved in producing OER (i.e., production, distribution, printing), this does not provide any information that can be used to assess potential savings against current LTSM costs incurred by government. The aggregated LTSM spend by province would need to be accompanied by detailed data regarding how many books and other resources were bought for how many learners and at what cost per unit. A breakdown of the cost as far as possible, indicating individual components such as procurement and distribution would better enable as potential cost-saving from OER to be calculated. While the absence of a LTSM line item in the DBE budget makes it impossible to calculate how much DBE money is being directed to LTSM production and distribution, this is not surprising due to the fact that it is the PDEs who are mandated to acquire and distribute LSTM. The DBE's role is one of primary oversight and policy formulation. However, providing 
accurate figures relating to any spend related to OER by the DBE (e.g., printing and distribution in the case of Siyavula) would assist in calculating if there is any cost benefit in using OER in the basic education system, which could inform policy decisions and textbook choices.

The question of how to source credible, authoritative data on financial resource allocation in the South African education system remains a challenge for all future research in this area. Targeted interviews conducted with authoritative sources could be a solution; however, as discovered when interviews were attempted during this research work, officials are reluctant to share financial data that is not already publicly available. The concept of OER is in the very early stages of being incorporated into policy, which may ultimately assist in tracking any expenditure in this area in the future, which is encouraging. While this study has provided a foundation for future research on the extent of public funding of OER in South African basic education, certain data-sourcing challenges remain and it is still to be determined whether and to what extent OER represent a cost reduction with regard to educational resource acquisition in South African basic education.

\section{References}

Allen, N., \& Student PIRGs. (2010). A cover to cover solution: How open textbooks are the path to textbook affordability. Washington: Center for Public Interest Research. Retrieved from http://www.studentpirgs.org/sites/student/files/reports/A-Cover-To-Cover-Solution 4.pdf

Attwell, A. (2012, January 5). A sea-change in South African schoolbook publishing. Retrieved from http://arthurattwell.com/2012/01/05/a-sea-change-in-south-african-schoolbook-publishing/

Brown, A., \& Green, T. (2015). Issues and trends in instructional technology: Leveraging budgets to provide increased access to digital content and learning opportunities. In M. Orey \& R. M. Branch (Eds.), Educational media and technology yearbook (pp. 11-21). Switzerland: Springer International.

Butcher, N., \& Hoosen, S. (2012). Exploring the business case for Open Educational Resources. Vancouver: Commonwealth of Learning. Retrieved from http://oasis.col.org/handle/11599/57

Creative Commons. (n.d.). About the licenses. Retrieved July 18, 2016 from http://creativecommons.org/licenses/.

Department of Basic Education. (n.d.). The Department of Basic Education. Retrieved July 18, 2016 from http://www.education.gov.za/TheDBE/tabid/54/Default.aspx

Department of Basic Education. (2009). Statement to national assembly by the minister of basic education on curriculum review process, 5 November 2009. Pretoria: Department of Basic Education. Retrieved from http://www.education.gov.za/ArchivedDocuments/ArchivedSpeeches/tabid/459/ctl/Details/mid L954/ItemID/2937/Default.aspx 
Department of Basic Education. (2011). Action plan 2014: Towards the realisation of schooling 2025. Pretoria: Department of Basic Education. Retrieved from http://www.education.gov.za/LinkClick.aspx?fileticket=jrxCoXJALPU\%3d\&tabid=418\&mid=121 $\underline{1}$

Department of Basic Education. (2012, 4 January). Statement during the announcement of the 2011 National Senior Certificate Grade 12 examination results by Mrs Angie Motshekga, Minister of Basic Education, National Library. Retrieved from http://www.gov.za/statement-duringannouncement-2011-national-senior-certificate-grade-12-examination-results-mrs

Department of Basic Education. (2013a). Annual performance plan 2013-2014. Pretoria: Department of Basic Education. Retrieved from http://www.education.gov.za/LinkClick.aspx?fileticket=SA2WZvctNMM\%3D\&tabid=358\&mid=1 $\underline{263}$

Department of Basic Education. (2013b). Report on the national School Monitoring Survey (DBEO13, conducted in 2011). Pretoria: Department of Basic Education. Retrieved from. http://www.education.gov.za/LinkClick.aspx?fileticket=nbaa\%2Bhb1H\%2Bw\%32D\&tabid=741\&m $\underline{\mathrm{id}=3176}$

Department of Basic Education. (2014). Draft national policy for the provision and management of Learning and Teaching Support Material (LTSM). Pretoria: Department of Basic Education. Retrieved from http://www.education.gov.za/LinkClick.aspx?fileticket=MnCEAX7Qrac\%3D\&tabid=390\&mid=11 $\underline{25}$

Department of Education. (1996a). National Education Policy Act No. 27 of 1996. Government Gazette, (Vol. 555, No. 34620). Retrieved from http://wced.pgwc.gov.za/documents/legislative acts/a271996.pdf

Department of Education. (1996b). South African Schools Act, No. 84 of 1996. Government Gazette, (Vol 377, No. 17579). Retrieved from http://www.gov.za/sites/www.gov.za/files/Act84of1996.pdf

Department of Education. (2006). South African Schools Act, 1996 (Act No 84 of 1996): Amended National Norms And Standards For School Funding. Pretoria: Government Printer. Retrieved from http://wced.pgwc.gov.za/circulars/circulars14/lgsp.html\#../circulars08/GG29179.pdf*e inf top .html\# 53 14.html

Development Bank of Southern Africa. (2012). Development report 2011: Prospects for South Africa's future. Halfway House: Development Bank of Southern Africa. Retrieved from http://www.dbsa.org/EN/About-Us/Publications/General/ DBSA\%20Development\%20Report\%202011.pdf 
Financial and Fiscal Commission. (2005). Annual submission for the division of revenue 2006/o7. Halfway House: Financial and Fiscal Commission. Retrieved from http://www.ffc.co.za/docs/submissions/dor/2006/fullreport.pdf

Frydenberg, J., \& Matki, G. W. (2007). Open textbooks: Why? What? How? When? Menlo Park: William and Flora Hewlett Foundation. Retrieved from http://www.hewlett.org/uploads/files/OpenTextbooks.pdf

Government Communications and Information Systems Department (2014). Education. Pretoria: GCIS. Retrieved from http://www.gcis.gov.za/sites/www.gcis.gov.za/files/docs/resourcecentre/Education2015.pdf

Hilton III, J., Robinson T. J., Wiley, D. A., \& Ackerman, J. (2014). Cost-savings achieved in two semesters through the adoption of Open Educational Resources. International Review of Research on Distance and Open Learning, 15(2). Retrieved from http://www.irrodl.org/index.php/irrodl/article/view/1700/2833

Jimes, C., Weiss, S., \& Keep, R. (2013). Addressing the local in localization: A case study of open textbook adoption by three South African teachers. Journal of Asynchronous Learning Networks, 17(2), pp 73-86. Retrieved from http://www.iskme.org/sites/default/files/kate/ adressing localization2013.pdf

Louw, P. (2015, July 27). Paperless classroom a reality. Retrieved from http://www.timeslive.co.za/thetimes/2015/07/27/Paperless-classroom-a-reality

National Treasury. (2014a). Eastern Cape vote o6: Education provincial budget 2014. Estimates of provincial revenue and expenditure standardised tables in Excel format. Pretoria: National Treasury of South Africa. Retrieved from http://www.treasury.gov.za/documents/provincial\%2obudget/2014/7.\%20Estimates\%20of\%20 Provincial\%20Revenue\%20and\%2oExpenditure\%20standardised\%20tables\%20in\%20Excel\%20 format/EC/EC\%20-\%20Education.xlsx

National Treasury. (2014b). Free State vote o6: Education provincial budget 2014. Estimates of provincial revenue and expenditure standardised tables in Excel format. Pretoria: National Treasury of South Africa. Retrieved from http://www.treasury.gov.za/documents/provincial\%2obudget/2014/7.\%20Estimates\%20of\%20 Provincial\%20Revenue\%20and\%20Expenditure\%20standardised\%20tables\%20in\%20Excel\%20 format/FS/FS\%20-\%20Education.xlsx

National Treasury. (2014c). Gauteng vote 05: Education provincial Budget 2014. Estimates of provincial revenue and expenditure standardised tables in Excel format. Pretoria: National Treasury of South Africa. Retrieved from http://www.treasury.gov.za/documents/provincial\%2obudget/2014/7.\%20Estimates\%20of\%20 Provincial\%20Revenue\%20and\%20Expenditure\%20standardised\%20tables\%20in\%20Excel\%20 format/GT/GT\%20-\%20Education.xlsx 
National Treasury. (2014d). KwaZulu-Natal vote 05: Education provincial Budget 2014. Estimates of provincial revenue and expenditure standardised tables in Excel format. Pretoria: National Treasury of South Africa. Retrieved from http://www.treasury.gov.za/documents/provincial\%2obudget/2014/7.\%20Estimates\%200f\%20 Provincial\%20Revenue\%20and\%20Expenditure\%20standardised\%20tables\%20in\%20Excel\%20 format/KZN/KZN\%20-\%20Education.xlsx

National Treasury. (2014e). Limpopo vote o3: Education provincial budget 2014. Estimates of provincial revenue and expenditure standardised tables in Excel format. Pretoria: National Treasury of South Africa. Retrieved from http://www.treasury.gov.za/documents/provincial\%20budget/2014/7.\%20Estimates\%200f\%20 Provincial\%20Revenue\%20and\%20Expenditure\%20standardised\%20tables\%20in\%20Excel\%20 format/LIM/LIM\%20-\%20Education.xlsx

National Treasury. (2014f). Mpumalanga vote 07: Education provincial budget 2014. Estimates of provincial revenue and expenditure standardised tables in Excel format. Pretoria: National Treasury of South Africa. Retreived from http://www.treasury.gov.za/documents/provincial\%2obudget/2014/7.\%20Estimates\%200f\%20 Provincial\%20Revenue\%20and\%20Expenditure\%20standardised\%20tables\%20in\%20Excel\%20 format/MPU/MPU\%20-\%20Education.xlsx

National Treasury. (2014g). Northern Cape vote 04: Education provincial Budget 2014. Estimates of provincial revenue and expenditure standardised tables in Excel format. Pretoria: National Treasury of South Africa. Retrieved from http://www.treasury.gov.za/documents/provincial\%2obudget/2014/7.\%20Estimates\%200f\%20 Provincial\%20Revenue\%20and\%20Expenditure\%20standardised\%20tables\%20in\%20Excel\%20 format/NC/NC\%20-\%20Education.xls

National Treasury. (2014h). North West vote o8: Education provincial Budget 2014. Estimates of provincial revenue and expenditure standardised tables in Excel format. Pretoria: National Treasury of South Africa. Retrieved from http://www.treasury.gov.za/documents/provincial\%2obudget/2014/7.\%20Estimates\%20of\%20 Provincial\%20Revenue\%20and\%20Expenditure\%20standardised\%2otables\%20in\%20Excel\%20 format/NW/NW\%20-\%20Education\%20and\%20Training.xls

National Treasury. (2014i). Western Cape vote 05: Education provincial budget 2014. Estimates of provincial revenue and expenditure standardised tables in Excel format. Pretoria: National Treasury of South Africa. Retrieved from http://www.treasury.gov.za/documents/provincial\%2obudget/2014/7.\%20Estimates\%200f\%20 Provincial\%20Revenue\%20and\%20Expenditure\%20standardised\%20tables\%20in\%20Excel\%20 format/WC/WC\%20-\%20Education.xls

National Treasury. (2015). Budget 2015: Estimates of national expenditure (vote 14 Basic Education). Pretoria: South African National Treasury. Retrieved from 
http://www.treasury.gov.za/documents/national\%20budget/2015/enebooklets/Vote\%2014\%20 Basic\%20Education.pdf

Nkosi, B. (2013, August 23). South Africa's hidden textbook crisis. Retrieved from http://mg.co.za/article/2013-08-23-00-south-africas-hidden-textbook-crisis

Organisation for Economic Co-operation and Development. (2008). Reviews of national policies for Education: South Africa. Paris: OECD Publishing. DOI:

http://dx.doi.org/10.1787/9789264053526-en

Pitt, B. \& Beckett, M. (2014a, June 30). Siyavula educator survey results: Educational contexts (Part II). Retrieved from http://oerhub.net/college/siyavula-educator-survey-results-sample-part-i/

Pitt, B. \& Beckett, M. (2014b, July 1). Siyavula educator survey results: Educational contexts (Part II). Retrieved from http://oerhub.net/collaboration-2/siyavula-educator-survey-results-educationalcontexts-part-ii/

Publishers' Association of South Africa. (2004). Print Industries Cluster Council report on intellectual property rights in the print industries sector. Cape Town: Print Industries Cluster Council. Retrieved from http://www.publishsa.co.za/downloads/intellectual property report.pdf

Republic of South Africa. (1996). Constitution of the Republic of South Africa, 1996. Retrieved from http://www.gov.za/documents/constitution/chapter-2-bill-rights\#29

Shillington, G. (2012, December 10). Is Siyavula the answer to South Africa's textbook crisis? Retrieved from http://ventureburn.com/2012/10/is-siyavula-the-answer-to-south-africas-textbook-crisis/

Siyavula. (2015a). About us: Our history. Retrieved from http://www.siyavulaeducation.com/abouthistory.html

Siyavula. (2015b). Our work: Partnered work and collaborations. Retrieved from http://www.siyavulaeducation.com/work-partnered.html

Spaull, N. (2012). South Africa at a glance: SACMEQ at a glance series. Stellenbosch: Research on Socioeconomic Policy (RESEP). Retrieved from http://resep.sun.ac.za/index.php/projects/

Supreme Court of Appeal of South Africa. (2015). Minister of Basic Education v Basic Education for All (20793/2014) [2015] ZASCA 198 (2 December 2015). Retrieved from http://www.justice.gov.za/sca/judgments/sca 2015/sca2015-198.pdf

Toledo, A., Botero, C. \& Guzmán, L. (2014). Public expenditure in education in Latin America: Recommendations to serve the purposes of the Paris Open Educational Resources Declaration. Open Praxis, 6(2), pp 103-113. Retrieved from https://oerknowledgecloud.org/sites/oerknowledgecloud.org/files/119-547-2-PB.pdf 
United Nations Educational, Scientific and Cultural Organisation International Institute for Educational Planning. (2010). In search of quality: What the data tell us. IIEP Newsletter, 28(3), pp 1-16. Retrieved from http://www.iiep.unesco.org/sites/default/files/nl_2010-3_en.pdf.

United Nations Educational, Scientific and Cultural Organisation Institute for Statistics. (2011). Financing education in Sub-Saharan Africa: Meeting the challenges of expansion, equity and quality. Canada: UNESCO Institute for Statistics. Retrieved from http://www.uis.unesco.org/Library/Documents/Finance_EN_web.pdf.

United Nations Educational, Scientific and Cultural Organisation. (2012). Paris OER Declaration. Retrieved from http://www.unesco.org/new/fileadmin/MULTIMEDIA/HQ/CI/CI/pdf/Events/Paris\%20OER\%2 oDeclaration 01.pdf

United Nations Development Programme. (2012). Achieve universal primary education: Where we are? Retrieved from http://www.za.undp.org/content/south_africa/en/home/post2015/mdgoverview/overview/mdg2/

United Nations Economic Commission for Africa. (2015). MDG report 2015: Assessing progress in Africa toward the millennium development goals. Addis Ababa: Economic Commission for Africa.

van Wyk, C. (2015). An overview of key data sets in education in South Africa. South African Journal of Childhood Education, 5(2), 146-170. Retrieved from http://www.scielo.org.za/scielo.php?script=sci_arttext\&pid=S222376822015000200008\&lng=en\&tlng=en

Wafawarowa, B. (2012). Supporting affidavit in the matter between Section 27, Hanyani Thomo Secondary School and Condani Lydia Masiphephethu versus Minister of Basic Education and Member of the Executive Council: Limpopo Department of Education. Retrieved from http://www.section27.org.za/wp-content/uploads/2012/05/Supporting-affidavit.pdf

Western Cape Government. (2015). New ePortal launched. Retrieved from https://www.westerncape.gov.za/elearning

Wiley, D., Hilton III, J. L., Ellington, S., \& Hall, T. (2012). A preliminary examination of the cost savings and learning impacts of using open textbooks in middle and high school science classes. The International Review of Research in Open and Distributed Learning, 13(3), 262-276. Retrieved from: http://www.irrodl.org/index.php/irrodl/article/view/1153/2256

\section{Athabasca University}

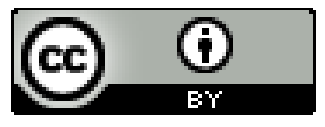

